\title{
Strategic Disclosure: The Case of Business School Rankings
}

\section{Citation}

Luca, Michael, and Jonathan Smith. "Strategic Disclosure: The Case of Business School Rankings." Working Paper. (Published in the Journal of Economic Behavior and Organization, April 2015.)

\section{Published Version}

http://www.sciencedirect.com/science/article/pii/S0167268114003369

\section{Permanent link}

http://nrs.harvard.edu/urn-3:HUL.InstRepos:11508216

\section{Terms of Use}

This article was downloaded from Harvard University's DASH repository, and is made available under the terms and conditions applicable to Open Access Policy Articles, as set forth at http:// nrs.harvard.edu/urn-3:HUL.InstRepos:dash.current.terms-of-use\#OAP

\section{Share Your Story}

The Harvard community has made this article openly available.

Please share how this access benefits you. Submit a story.

Accessibility 


\title{
Strategic Disclosure: The Case of Business School Rankings ${ }^{1}$
}

\author{
Michael Luca ${ }^{2}$ and Jonathan Smith ${ }^{3}$
}

November 2014

\begin{abstract}
We empirically analyze disclosure decisions made by 240 MBA programs about which rankings to display on their websites. We present three main findings. First, consistent with theories of countersignaling, top schools are least likely to disclose their rankings, whereas mid-ranked schools are most likely to disclose. Second, schools that do poorly in the U.S. News rankings are more likely to disclose their Princeton Review certification, suggesting that schools treat different certifications as substitutes. Third, conditional on displaying a ranking, the majority of schools coarsen information to make it seem more favorable. The stark patterns in the data help to provide empirical evidence on the strategic elements of voluntary disclosure and marketing decisions.
\end{abstract}

Keywords: Voluntary Disclosure, Information Unraveling, Marketing, Countersignaling, Rankings

\footnotetext{
${ }^{1}$ We thank Max Bazerman, David Laibson, William Neilson, and two anonymous reviewers for helpful comments and suggestions. We also thank Patrick Rooney for excellent research assistance. All remaining errors are our own.

${ }^{2}$ Harvard Business School, Soldiers Field Road, Boston, MA 02163. mluca@hbs.edu

${ }^{3}$ The College Board - Washington, D.C. jsmith@collegeboard.org
} 


\section{Introduction}

One of the most well-known theories of voluntary disclosure relates to an idea known as information unraveling (Grossman 1981, Milgrom 1981, Jovanovic 1982). Considering a setting in which there is a single dimension of product quality, these models argue that organizations will disclose information about their quality if disclosure costs are low and the information is favorable. In equilibrium, consumers infer that firms that do not disclose their quality are likely to be worse than firms that do. Therefore, through the unraveling process, higher-quality firms should have an incentive to reveal information about their product quality, which should then put pressure on all firms to disclose. However, predicted patterns of voluntary disclosure can be qualitatively different when we take into account additional features that are prevalent in a variety of real-world settings, such as multiple signals of quality and customers' prior beliefs.

A leading example of how the traditional unraveling result might break down is presented in Feltovich, Harbaugh, and To (2002), who show that disclosure patterns can be non-monotonic, with middle-performing firms disclosing their quality while top-performing firms choose to withhold information. This "countersignaling" occurs because a high quality firm withholding information signals to potential customers that they are confident that other information about them will be favorable. Feltovich et al. (2002) suggest that such countersignaling may underlie a wide variety of situations, such as the differences between the ostentatious displays of the nouveau riche and the more measured outward approach of old-moneyed families. Psychologists have also investigated ideas related to countersignaling. Bellezza et al. (2014) demonstrate that employees can be perceived to be of higher status when they choose not to conform to a workplace norm (for example, by dressing casually when business dress is the standard). Moreover, a high quality firm's benefit to disclosing information may be outweighed by the cost of disclosure if consumers already have precise prior beliefs about the very best firms. To date, there is little empirical evidence of situations in which high quality firms are choosing to countersignal while lower quality firms are disclosing information.

In this paper, we graphically and statistically test for unraveling and countersignaling by collecting and analyzing the rankings displayed on the websites of 240 top-ranked U.S. business schools. Business schools provide a rich empirical context in which to test for patterns of voluntary disclosure of quality reports for several reasons. First, rankings have been shown to have a large effect on applicants' decisions (Bowman and Bastedo 2009, Meredith 2004, Monks and Ehrenberg 1999) and admissions decisions (Conlin et al. 2013). Hence, business schools have the incentive to be strategic in their disclosure decisions. Second, rankings are verifiable, a condition stipulated in the unraveling literature. Third, business schools are ranked by many media outlets. Even within a media outlet, such as U.S. News and World Report, multiple rankings of MBA programs exist (for example, "Best Evening MBA Program" and "Best MBA Program in New England"). Hence, business schools face a strategic decision about which rankings, if any, to reveal rankings on their websites. Fourth, education decisions are among the 
most significant choices many people will make in their lifetime and students and policymakers are interested in improving the decision making process.

Turning to the data, we find large amounts of voluntary disclosure of rankings; 65 percent of the schools in our sample publish or mention at least one ranking on their main websites. We find that disclosure decisions are non-monotonic as a function of a school's rank: top schools are least likely to display their rankings, mid-ranked schools are most likely to display their rankings, and bottom-ranked schools fall in between. These findings are largely consistent with the idea of countersignaling. We also find that schools that have a branded name, as measured by the count of mentions in the New York Times, are less likely to disclose rankings on their website, which provides further evidence consistent with consumers' priors from competing signals influence whether a school discloses information.

Beyond these main results, we consider two other features that are common to many disclosure settings but are not captured in the basic unraveling result. First, organizations choose not only whether to reveal information, but what information to reveal - and can hence select certain dimensions over others. Whereas the existing literature has demonstrated that voluntary disclosure of a single dimension of quality information is incomplete (Dranove and Jin 2010, Mathios 2000, Jin and Leslie 2003) and that disclosure rates depend on factors such as the amount of competition (Jin 2005) and cost of disclosure (Lewis 2010), the idea of selective disclosure focuses on situations in which there are multiple pieces of information that a firm can choose to disclose.

Second, there is growing evidence that consumers respond differently to information when it is visible or salient than when it is shrouded or opaque (Pope 2009, Brown et al. 2010, Luca and Smith 2013). In these settings, Gabaix and Laibson (2006) show theoretically that information revelation can break down. Even when an organization chooses to disclose information, they may still choose to shroud certain pieces of information that would make the organization look less favorable.

These ideas lead us to two additional empirical results regarding voluntary disclosure. First, we show that schools selectively reveal favorable rankings. For example, schools that do poorly or are unranked in U.S. News and World Report are more likely to display an Association to Advance Collegiate Schools of Business (AACSB) accreditation or mention that they made Princeton Review's list of top overall business schools, which is a pooled group with no explicit rank. In fact, exactly zero of the top-50 schools mention that they are included on Princeton Review's unordered list of top programs, while 30\% of unranked schools mention that they are on the list. This suggests that schools treat different rankings and accreditations as substitutes for each other.

Second, conditional on displaying a ranking, the majority of schools coarsen information to make it seem more favorable - for example, saying "top-ranked program" instead of "topranked program in the Northeast," or "top 20" instead of "ranked number 20." Overall, each individual ranking is verifiable, but selective disclosure and shrouding of information may undermine market mechanisms of voluntary information disclosure. 
Overall, these findings shed new light on equilibrium patterns of voluntary disclosure in a context in which the information being disclosed is relevant to customers and the discloser has significant freedom to disclose or not. In particular, we provide novel field evidence consistent with countersignaling, which was first modeled by Feltovich et al (2002). Moreover, we analyze the type of multidimensional disclosure problem that is common in the field, whereas most of this literature has focused on single-dimensional disclosure problems. Our results show that there is significant substitutability between information sources. Finally, drawing on the idea of shrouded attributes, we are able to relax the assumption that schools will either disclose truthfully or not disclose at all, and show that the vast majority of schools engage in some sort of shrouding.

\section{Data}

This analysis uses two types of data. First, we compile a set of U.S. business schools that are ranked in a number of different sources, as we refer to them, including U.S. News \& World Report (USNWR), Bloomberg Business Week, Princeton Review, The Economist, Forbes, and The Financial Times. These are popular sources of rankings that can be found on the Internet or on newsstands.

We designate rankings into one of two categories: overall or specialty. Overall rankings are those that rank each business school as a whole; specialty rankings are those that rank specific programs (e.g., top part-time or executive MBA programs) or a specific set of schools (e.g., top program in New England or at a public university). Collectively, we refer to these as different types of rankings.

With the exception of Princeton Review, all sources have an explicit ranking for top overall business schools. Princeton Review publishes a list of top overall MBA programs, but it pools the programs into a single group rather than explicitly ranking them. USNWR, Bloomberg Business Week, and Princeton Review also have specialty rankings. Any school listed in any of the aforementioned six sources or given any type of rank is included in the final set of 240 business schools. ${ }^{4}$ Across all sources, we have 38 distinct overall and specialty rankings and hence 38 distinct variables. ${ }^{5}$

Summary statistics of the ranking can be seen in Table 1. The variables that include "best" take the minimum (best) rank across each source. The average USNWR overall rank is 55.5. The average overall rank across sources is slightly lower (49) because the sources other than USNWR do not rank as many programs. The best overall or specialty rank is 56.8. On average, schools show up in 1.6 overall rankings and 3.2 specialty rankings.

To obtain our second type of data, we visited each business school's website in search of any mention of rankings, ${ }^{6}$ looking specifically at the school's homepage, the page of its graduate

\footnotetext{
${ }^{4}$ These ranks were available online in the spring of 2012 but typically come out in are released the previous fall.

${ }^{5}$ A complete list of type of rankings is included in Appendix 1. When a business school is not in a ranking, it is coded as missing.

${ }^{6}$ We visited the websites in spring 2012, well after the release of the rankings.
} 
program within the business school, and the page of its MBA program. ${ }^{7}$ We did not search the entire website for each business school, despite the fact that business schools often display ranking information on their "About" webpage, "Admissions" webpage, or brochures. Our analysis concentrates only on both common webpages and salient displays of rankings.

Schools mention and display rankings in a variety of ways. Some schools mention their overall rank (e.g., "Ranked \#9 business school according to The Financial Times"), some schools mention specialty rankings (e.g., "Ranked \#3 part-time MBA program in USNWR"), and some schools just mention the source (e.g., "Top business school according to Business Week"). To capture the various ways in which schools mention rankings of the five rankers (USNWR, Business Week, The Economist, Forbes, and The Financial Times), we create three indicator variables with the following definitions:

1. Website Mentions Any Rank - equals one if the business school's website mentions any of the five rankers in any capacity, zero otherwise.

2. Website Mentions Overall Rank - equals one if the business school's website mentions any of the five rankers' overall rank, zero otherwise.

3. Website Mentions Specialty Rank - equals one if the business school's website mentions any of the five rankers' specialty ranks, zero otherwise.

4. Website Mentions Only Source - equals one if the business school's website mentions any of the five sources, with no specific rankings, zero otherwise.

These variables are not mutually exclusive from one another, and schools that mention numerous different ranks are not differentiated from schools that mention one rank. Table 1's summary statistics of these variables show that, in aggregate, 45 percent of schools mention any rank from the five sources. Many of the rankings mentioned are specialty rankings; only 15 percent of schools mention the overall rankings, and 8 percent mention only the source.

Schools frequently mention lesser-known rankings and the Princeton Review's specialty rankings. Thus, we create four more variables, identical to the previous four but with mentions of these other rankings included. ${ }^{8}$ As Table 1 shows, these four variables are greater than (or equal to) the previous four, and 65 percent of schools mention any of these ranks. ${ }^{9}$

The next few variables in Table 1 show the prevalence of being mentioned on a website for each source. USNWR, Business Week, and Princeton Review are mentioned on schools' websites, in any capacity, 32, 21, and 23 percent of the time, respectively. Note that the Princeton Review mentions are quite frequently the pooled overall top 300-business schools rank, which we separately analyze. This overall rank is mentioned 18 percent of the time.

\footnotetext{
${ }^{7}$ Sometimes these web pages are one and in the same or do not exist. If there is a choice on the MBA program webpage, we select the full-time program.

${ }^{8}$ Common other rankings include Princeton Review's specialty rankings, Poets \& Quants, and Aspen Institute.

${ }^{9}$ This statistic includes those schools that simply say that the school is ranked and provide no additional information. Excluding these few non-specific mentions of rankings will not change future results.
} 
The next few outcome variables in Table 1 are various ways in which schools either present rankings that pool them with other top schools or shroud information. The first variable, Website Mentions Highly Ranked With No Additional Information, equals one when a school simply says it is highly ranked and zero otherwise. The 12 percent of schools that do this do not mention the source, the type of ranking, or even the rank.

The next variable is Website Mentions AACSB. The Association to Advance Collegiate Schools of Business (AACSB) is an accreditation organization that only accredits approximately 5 percent of business schools worldwide, including almost all schools in this sample. Most of the 57 percent of schools that mention AACSB simply post the AACSB logo on their website.

The last outcome variable is Website Shrouds Information, which documents when there is a lack of potentially informative details coupled with some mention of rankings. Admittedly, schools cannot include every piece of ranking information on their website. Yet some schools seem to be deliberately shroud information-for example, saying only that they are "top ranked," or, less dramatically, that they are "ranked top 20 " when they fall in the $20^{\text {th }}$ position. Similarly, posting rankings from past years with no mention of the current year's rankings qualifies as shrouding information. Appendix 2 presents a complete list of the ways we document shrouding. Conditional on mentioning ranks, 72 percent of schools shroud details.

The last two variables in Table 1 are obtained online from the New York Times website. The first variable is the count of the number of times the university is mentioned in the New York Times. The second is the count for the business school associated with the university. These measures, with relatively high means, represent a measure of potential exposure to information about a school.

\subsection{Who Gets Ranked?}

Using the five overall rankings sources, we find that each source ranks a different number of programs. Even where there is overlap in the number of programs ranked, there is no agreement on which programs are the best. To demonstrate the lack of agreement, Table 2 displays the counts of unique programs in several buckets of ranks. Generalizing beyond business-school rankings, in markets where more disagreement exists among ranking sources, there will be more scope for firms to selectively disclose information.

As shown in Table 2, across our five sources, there are 15 different top 10 programs and 21 programs ranked 11-20. Each of the next few buckets, through 61-70, has no less than 26 unique schools in its ten possible slots. Thus, the lower the rank, the more disagreement across sources there seems to be. Buckets greater than 70 have fewer unique schools, but this is due in part to the fact that because some of our sources do not rank this many programs. 


\section{Empirical Analysis}

In this section, we investigate patterns of voluntary disclosure, testing for unraveling and countersignaling, selective disclosure, and shrouding. For each of these phenomena, we provide a graphical analysis and then present the supporting regressions.

\subsection{Empirical Specification}

Throughout this section, we will rely on the same general specification and only vary the outcome variables. The main specification is as follows:

OUTCOME $_{s}=\alpha_{0}+\alpha_{1} I(11-25)_{s}+\alpha_{2} I(26-50)_{s}+\alpha_{3} I(51-75)_{s}+\alpha_{4} I(76-116)_{s}+\alpha_{5} I(\text { unranked })_{s}+\eta_{s}$

where OUTCOME $_{s}$ is the outcome of interest for school $s . I(\cdot)_{s}$ is an indicator equal to one if the overall rank of business school $s$ falls within the range noted in the parentheses and equals zero otherwise. The overall rank comes from USNWR, which goes up to $116{ }^{10}$ Schools that are "unranked" show up in some source and type of rankings, but not in the USNWR overall rank. The omitted variable is the set of schools ranked 1-10 and the set of $\alpha$ 's are the coefficient that describe how likely the range of schools are to fall into the outcome variable, relative to schools ranked 1-10. Finally, $\eta_{s}$ is a random error term that is assumed to be uncorrelated with the outcome variable.

We estimate all specifications using OLS and robust standard errors. ${ }^{11}$

\subsection{Unraveling and Countersignaling}

Figure 1 graphically tests for unraveling and countersignaling. Consistent with the idea of countersignalling, we find that disclosure is non-monotonic in the school's ranking; that is, topranked schools are least likely to disclose their rankings. If one truncates the distribution and only looks at schools ranked 26 and lower, the traditional unraveling result emerges; over 80 percent of these schools mention ranks. These middle-ranked schools are most likely to disclose their ranking; the rate of disclosure declines for lower-ranked schools.

Table 3 tests the statistical robustness of these results. Column 1 (Any Rank) are results from when the dependent variable equals one if the website mentions any rank from the five sources and zero otherwise- one of our broad measures of disclosure. The coefficient on the indicator variable ranked 11-25 equals 0.109 but is not statistically different than zero. On the other hand, the coefficient on schools ranked 26-50 equals 0.659 and is statistically significant. This means that relative to schools ranked 1-10, schools ranked 26-50 are 65.9 percentage points more likely

\footnotetext{
${ }^{10}$ Alternatively, we use best overall rank across the five sources. Results are not sensitive to the alternate definition but are presented in the appendices.

${ }^{11}$ All results are robust to using a probit model.
} 
to mention or display any rank. Similarly, schools ranked 51-75 are more than 56 percentage points more likely than a top 10 school to mention a ranking. However, both schools ranked from 76-116 and unranked schools are just over 30 percentage points more likely to mention a rank than are top 10 schools, which is statistically less than the likelihood of schools ranked 2650 mentioning a rank. ${ }^{12}$ Overall, a clear non-linearity emerges in this sample, such that the best and worst schools are less likely than middle-ranked schools to mention rankings on their websites.

Columns 2 and 3 repeat this specification, but break the dependent variable of ranking mentions into rankings of overall rankings (e.g., best school overall) and specialty rankings (e.g., within a region or according to a specialty). Column 2 presents results when the outcome variable is Overall Rank, which does not include mention of a specialty ranking. The only coefficient that is large in magnitude and statistically different than zero is the indicator for schools ranked 26-50. The coefficient implies that those schools are 28.4 percentage points more likely to mention rankings than top 10 schools. Column 3 uses Specialty Rank as a dependent variable. All coefficients are positive and statistically different than zero. Here, we see the nonlinearity that was driving the results in the first column, where schools ranked between 26 and 75 are much more likely to mention rankings than top 10 schools and also more likely than the other schools, albeit less so.

Columns 4-6 present the same specifications but expand the set of ranking institutions (columns 1-3 only include the five most popular institutions), and Column 4 corresponds to Figure 1. We still see a non-monotonic pattern where the mid-ranked schools are statistically more likely than the best and worst schools to mention rankings.

\subsubsection{Why Do Schools Countersignal?}

One should expect business schools to disclose their rankings when the benefit of doing so is greater than the cost. In this context, the cost of disclosure (on the school's website) is very low. Virtually all business schools regularly update their websites with news about their school, students, and faculty, so the cost of posting a ranking online is trivial. One might think that space is the limiting factor, but there is a significant amount of open space on many of these websites. Moreover, displaying a ranking takes very little space. Hence, it seems unlikely that high costs are prohibitive in this situation - especially in light of the high overall rates of disclosure.

Given this, why don't top schools disclose their rankings? Consistent with the countersignaling model of Feltovich et al. 2002, mid-ranked schools may be able to separate themselves from low-ranked schools by posting their rankings. However, applicants likely already know that schools such as Stanford are high quality. Top schools can then

\footnotetext{
${ }^{12}$ We tested this using an F-Test. Unranked schools are also statistically less likely to mention ranks than schools ranked 51-75.
} 
"countersignal," or show that they don't need to disclose their rankings because they know that other information about them is so favorable.

More generally, the prior beliefs of applicants influence the benefits of disclosure. For example, looking at public and "market-oriented" report cards of Medicare HMOs, Dafny and Dranove (2008) show that consumers respond more in situations where there is a large variance

in HMO quality (in other words, when prior beliefs are imprecise). In situations where reports present information that customers already have and hence only serve to confirm prior beliefs, reports do not have an impact on decisions. In our setting, prior beliefs also play an important role. While it could be the case that students generally know more about top schools (and hence have more precise priors in this part of the ranking distribution), existing work has demonstrated that rankings influence application behavior at all parts of the distribution (Monks and Ehrenberg 1999, Smith and Luca 2013, Reback and Alter 2014). Moreover, the impact on student decisions is especially large for the top schools, as demonstrated by Bowman and Bastedo (2009), who show that getting on the front page of USNWR rankings has a large impact on applications. Despite the fact that rankings have some informational value at all parts of the distribution, top schools still find countersignaling to be an optimal strategy.

\subsubsection{Branded Schools}

More generally, if a school's quality is well known to applicants, then it will face different incentives to disclose its rankings. To test this idea, we examine whether business schools that are mentioned in the New York Times more frequently are less likely to disclose. Column 1 shows that when the university as a whole is frequently written about in the New York Times, there is a negative but insignificant effect on the probability of disclosing a rank on the school's website. However, a one percent increase in the business school being written about in the New York Times corresponds to a 4.1 percentage point decrease in the probability of disclosing a rank on the website. The next few columns test the sensitivity of these results and the qualitative result holds- business schools that are more frequently written about are less likely to disclose. This is consistent with the hypothesis that a school's disclosure decision is influenced by other information that students are receiving.

\subsection{Selective Disclosure}

Many business school ratings produce an ordinal ranking of a set of schools. However, there are two information sources - the Princeton Review overall ranking and AACSB certification that simply provide a list of accredited or "top" schools. These lists provide a certification to hundreds of schools, but do not differentiate between the quality of the different schools. Hence, a school that is ranked number 100 and a school that is ranked 1 would receive the same rating in these systems. These ratings should then be most attractive to schools with lower rankings, which can attempt to pool themselves with top schools and to separate themselves from schools 
that fall outside of the lists. In contrast, top schools may again prefer to countersignal by withholding this information, given the fact that students likely know that top schools would be on this list and the fact that top schools have little incentive to try to pool with middle-ranked schools.

To test this, we analyze the decision to disclose Princeton Review and AACSB ratings as a function of how a school does on the U.S. News \& World Report Ranking. Figure 2 displays the result. Again consistent with the countersignaling hypothesis, no top 10 schools mention this information. There is a steady increase in both outcomes as the rank gets worse, and unranked schools are much more likely thank ranked schools to mention this information. In fact, 78 percent of unranked schools mention that they are AACSB certified.

Table 6 presents these results in the form of a regression. The first column's outcome variable is School's Website Mentions Princeton Review Overall Rank. The first few coefficient estimates indicate that there are no differences in the likelihood of mentioning this rank among the top 50 schools. The next two coefficients increase in magnitude, and the coefficient on unranked schools jumps to 0.305 and is statistically different than zero. This means that unranked schools are over 30 percentage points more likely to mention (or display) that they are ranked among the best by Princeton Review than are top-ranked schools.

The second outcome variable is School's Website Mentions AACSB Certification. Moving down the table, the coefficient estimates steadily increase. In other words, schools ranked relatively low are more likely to advertise the accreditation than the best-ranked schools. In fact, the lowest-ranked schools and unranked schools are 64 and 78 percentage points, respectively, more likely to mention AACSB than the top 10 schools.

Overall, top ranked schools withhold this information while middle-ranked, low-ranked, and unranked schools tend to advertise these coarse signals. ${ }^{13}$.

\subsection{Shrouding}

Returning to Figure 1, we see that most schools shroud information. The unconditional likelihood of shrouding is highest for the middle-ranked schools, but only because middle-ranked schools are most likely to disclose information. Conditional on displaying a ranking, levels of shrouding are not materially different across different parts of the ranking distribution. Table 5 presents the corresponding regressions on various forms of shrouding. The first column of Table 5 is School's Website Mentions Top Ranked with No Supporting Information. Despite the fact that information is verifiable in this setting, this analysis shows that shrouding is still extremely prevalent.

Why do schools shroud? Based on the existing literature, we know that small changes, such as making information more or less salient to students, affect their decisions (Bowman and Bastedo 2009, Luca and Smith 2013, Pallais forthcoming). Hence, this is a setting where shrouding may be an effective strategy. Moreover, Bowman and Bastedo (2009) show that

\footnotetext{
${ }^{13}$ Appendix 4 presents consistent results when using "Best Overall Rank" in place of USNWR overall rank.
} 
schools benefit from being on the first page of the U.S. News \& World Report rankings. This suggests that student response to rankings is coarse - which could help to explain why schools coarsen information.

\section{Discussion}

The results of this paper suggest that, taken in aggregate, voluntary information disclosure is more nuanced than full or no disclosure. In the context we study, voluntary disclosure seems to be a function of the existing brand: schools at the very top countersignal by withholding quality reports, but partial unraveling occurs lower in the ranks. Moreover, most schools that mention rankings also shroud details. Even when reports are of high quality and completely verifiable, firms can choose how to present a result.

While we have focused on a business school's decisions about what information to disclose, we expect the insights of this paper to generalized to a wide variety of settings. For example, there has been a proliferation of information sources about product quality in recent decades; rankings, certifications, and quality reports abound. While consumers may go directly to each of these sources, all firms also face a strategic decision about which pieces of information - if any to voluntarily present to consumers. Restaurants frequently display their Yelp rating, Zagat score, newspaper reviews, and other endorsements. Car companies announce their results from Car \& Driver, JD Power, and Consumer Reports. Our findings help to provide insight into the strategic elements of disclosure decisions that organizations regularly face. 


\section{References}

Bellezza, Silvia, Francesca Gino, and Anat Keinan, 2014. "The Red Sneakers Effect: Inferring Status and Competence from Signals of Nonconformity" Journal of Consumer Research, Vol. 41, No. 1, 35-54.

Bowman, Nicholas, and Michael Bastedo, 2009. "Getting on the Front Page: Organizational Reputation, Status Signals, and the Impact of U.S. News and World Report on Student Decisions," Research in Higher Education. Vol. 50, No. 5.

Brown, Alexander, Colin Camerer, and Dan Lovallo, 2012. "To Review or Not to Review? Limited Strategic Thinking at the Movie Box Office," American Economic Journal: Microeconomics, Vol. 4, No. 2, 1-26.

Brown, Jennifer, Tanjim Hossain, and John Morgan, 2010. "Shrouded Attributes and Information Suppression: Evidence from the Field," Quarterly Journal of Economics, Vol. 125, No. 2, 859-876.

Conlin, Michael, Stacy Dickert-Conlin, and Gabrielle Chapman, 2013. "Voluntary Disclosure and the Strategic Behavior of Colleges," Journal of Economic Behavior \& Organization, Vol. $96,48-64$.

Dafny, Leemore and David Dranove, 2008. Do Report Cards Tell Consumers Anything They Don't Already Know? The Case of Medicare HMOs. RAND Journal of Economics, Vol. 39, No. 3, 790-821.

Dranove, David and Ginger Jin, 2010. "Quality Disclosure and Certification: Theory and Practice," Journal of Economic Literature, Vol. 48, No. 4.

Gabaix, Xavier and David Laibson, 2006. "Shrouded Attributes, Consumer Myopia, and Information Suppression in Competitive Markets," Quarterly Journal of Economics, Vol. 121, No. 2, 505-540.

Grossman, Sanford, 1981. "The informational Role of Warranties and Private Disclosure about Product Quality”, Journal of Law and Economics, Vol. 24, 461-489.

Feltovich, Nick, Rick Harbaugh, and Ted To, 2002. "Too Cool for School: Signaling and Countersignalling”, RAND Journal of Economics, Vol. 33, No. 4, 630-649.

Finkelstein, Amy, 2009. "E-ZTAX: Tax Salience and Tax Rates," Quarterly Journal of Economics, Vol. 124, No. 3, 969-1010.

Forbes, Silke, Mara Lederman, and Trevor Tombe, forthcoming. "Quality Disclosure Programs and Internal Organizational Practices: Evidence from Flight Delays," American Economic Journal-Microeconomics.

Jin, Ginger, 2005. "Competition and Disclosure Incentives: An Empirical Study of HMOs," RAND Journal of Economics, Vol. 26, 93-113. 
Jin, Ginger and Phillip Leslie, 2003. "The Effect of Information on Product Quality: Evidence from Restaurant Hygiene Grade Cards," Quarterly Journal of Economics, Vol. 118, No. 2, 409451.

Jin, Ginger and Alan Sorensen, 2006. "Information and Consumer Choice: The Value of Publicized Health Plan Ratings," Journal of Health Economics, Vol. 26, No. 2.

Jovanovic, Boyan, 1982. “Truthful Disclosure of Information”, Bell Journal of Economics, Vol. $13,36-44$.

Lewis, Greg, 2010. "Asymmetric Information, Adverse Selection and Online Disclosure: The Case of eBay Motors," American Economic Review ,Vol. 101, No. 4.

Luca, Michael and Jonathan Smith, 2013 "Salience in Quality Disclosure: Evidence from the US News College Rankings," Journal of Economics and Management Strategy. Vol. 22(1): 58-77.

Luca, Michael and Giorgos Zervas, 2013. "Fake It Till You Make It: Reputation, Competition, and Yelp Review Fraud," working paper.

Marcus, Jon, 2013. "Caught cheating: Colleges falsify admissions data for higher rankings," NBC News.

Mathios, Alan, 2000. "The Impact of Mandatory Disclosure Regulations on Health Choices: An Analysis of the Salad Dressing Market," Journal of Law and Economics, Vol. 43, 651-678.

Meredith, Marc, 2004. "Why Do Universities Compete in the Ratings Game? An Empirical Analysis of the Effects of the USNWR College Rankings," Research in Higher Education, Vol. 45, No. 5.

Milgrom, Paul, 1981. "Good News and Bad News: Representation Theorems and Applications", Bell Journal of Economics, Vol. 12, 380-391.

Monks James, and Ronald Ehrenberg, 1999. "U.S. News and World Report's College Rankings: Why Do They Matter?," Change, Vol. 31, No. 6, 42-51.

Pallais, Amanda, forthcoming. "Small Differences that Matter: Mistakes in Applying to College," Journal of Labor Economics.

Pope, Devin, 2009. "Reacting to Rankings: Evidence from 'America's Best Hospitals',' Journal of Health Economics, Vol. 28, No. 6, 1154-1165.

Reback, Randall and Molly Alter, 2014. "True for Your School? How Changing Reputations Alter Demand for Selective U.S. Colleges," Educational Evaluation and Policy Analysis, Vol. 36, No. 1.

Sun, Monic 2011. "Disclosing Multiple Product Attributes," Journal of Economics and Management Strategy, Vol. 20, 195-224. 
$\underline{\text { Tables }}$

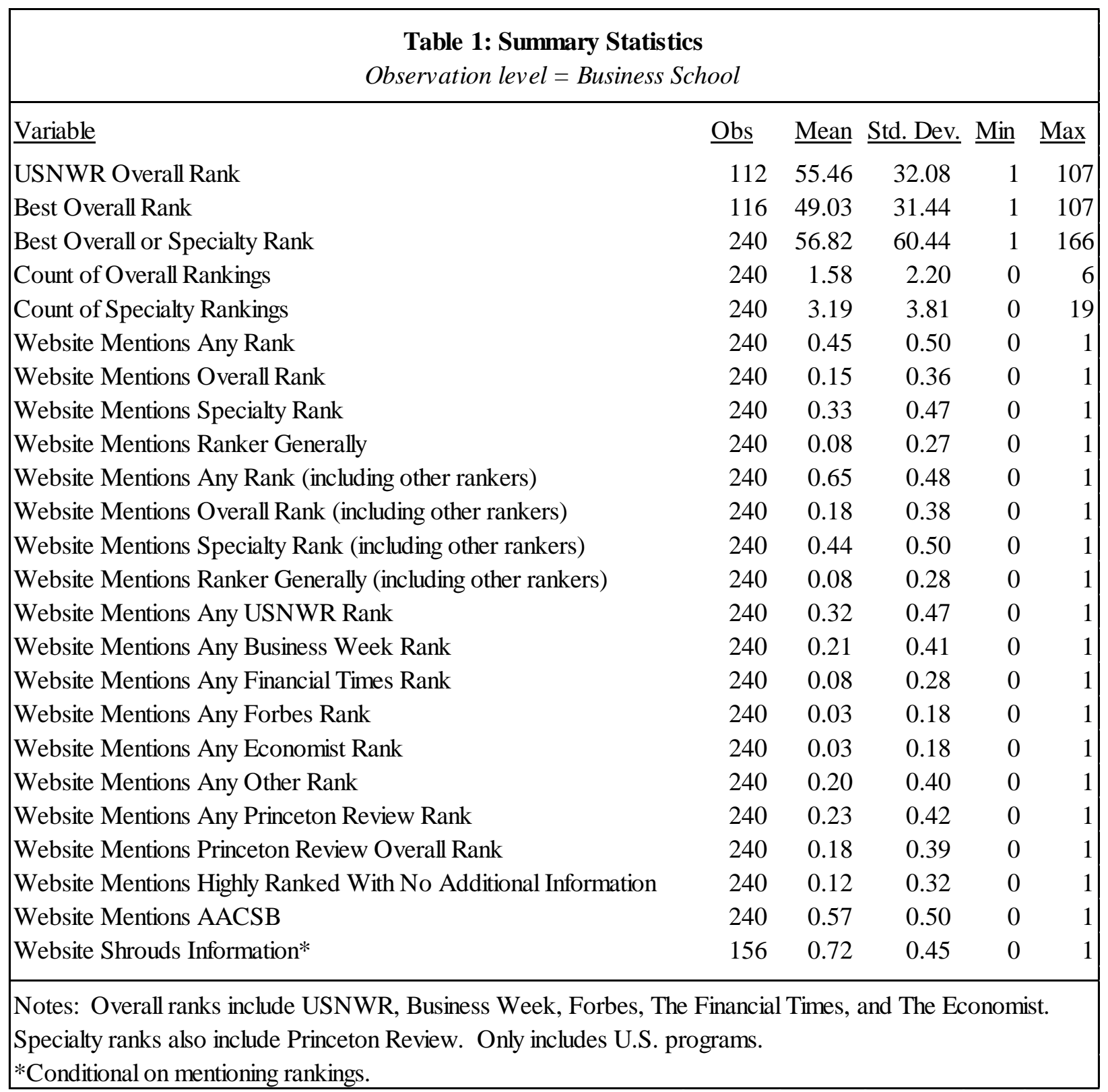




\begin{tabular}{|lc|}
\hline \multicolumn{1}{|c|}{ Table 2: There are 15 Top-10 Programs } \\
\hline Rank Category & \# of Programs \\
\hline Ranked 1-10 & 15 \\
Ranked 11-20 & 21 \\
Ranked 21-30 & 26 \\
Ranked 31-40 & 30 \\
Ranked 41-50 & 26 \\
Ranked 51-60 & 33 \\
Ranked 61-70 & 29 \\
Ranked 71-80 & 22 \\
Ranked 81-90 & 16 \\
Ranked 91-100 & 16 \\
\hline & \\
Notes: This table shows the number of schools that are ranked in a \\
given range according to at least one source of rankings. For \\
example, there are 15 programs that could claim to be top-10 based \\
on at least one ranking. Ranking include USNWR, Business Week, \\
Forbes, The Financial Times, and The Economist. Only includes \\
U.S. programs. \\
\hline
\end{tabular}




\begin{tabular}{|c|c|c|c|c|c|c|}
\hline \multirow[b]{3}{*}{ Variable } & \multicolumn{6}{|c|}{$\begin{array}{c}\text { Table 3: Test of Unraveling } \\
\text { Linear Probability Model } \\
\text { Omitted Variable = Top } 10 \text { Business School } \\
\text { Dependent Variable }=1 \text { if Ranking is Displayed, O Otherwise }\end{array}$} \\
\hline & \multicolumn{3}{|c|}{ Displays Ranking by Five Major Rankers } & \multicolumn{3}{|c|}{ Displays Ranking by Any Ranker } \\
\hline & $\underline{\text { Any Rank }}$ & $\underline{\text { Overall Rank }}$ & $\underline{\text { Specialty Rank }}$ & $\underline{\text { Any Rank }}$ & $\underline{\text { Overall Rank }}$ & Specialty Rank \\
\hline Ranked 11 - 25 & $\begin{array}{c}0.109 \\
(0.137)\end{array}$ & $\begin{array}{l}-0.024 \\
(0.109)\end{array}$ & $\begin{array}{l}0.200^{*} \\
(0.105)\end{array}$ & $\begin{array}{c}0.309 * * \\
(0.155)\end{array}$ & $\begin{array}{l}-0.024 \\
(0.109)\end{array}$ & $\begin{array}{l}0.200^{*} \\
(0.105)\end{array}$ \\
\hline Ranked 26 - 50 & $\begin{array}{c}0.659 * * * \\
(0.125)\end{array}$ & $\begin{array}{c}0.284 * * \\
(0.133)\end{array}$ & $\begin{array}{c}0.583 * * * \\
(0.102)\end{array}$ & $\begin{array}{c}0.784 * * * \\
(0.111)\end{array}$ & $\begin{array}{c}0.284 * * \\
(0.133)\end{array}$ & $\begin{array}{c}0.625^{* * *} \\
(0.100)\end{array}$ \\
\hline Ranked 51 - 75 & $\begin{array}{c}0.564 * * * \\
(0.125)\end{array}$ & $\begin{array}{c}0.047 \\
(0.109)\end{array}$ & $\begin{array}{c}0.552 * * * \\
(0.094)\end{array}$ & $\begin{array}{c}0.668 * * * \\
(0.119)\end{array}$ & $\begin{array}{c}0.047 \\
(0.109)\end{array}$ & $\begin{array}{c}0.655^{* * * *} \\
(0.089)\end{array}$ \\
\hline Ranked 76 - 116 & $\begin{array}{c}0.364 * * * \\
(0.124)\end{array}$ & $\begin{array}{c}0.030 \\
(0.105)\end{array}$ & $\begin{array}{c}0.273 * * * \\
(0.079)\end{array}$ & $\begin{array}{c}0.576 * * * \\
(0.121)\end{array}$ & $\begin{array}{c}0.091 \\
(0.111)\end{array}$ & $\begin{array}{c}0.455^{* * *} \\
(0.088)\end{array}$ \\
\hline Unranked & $\begin{array}{c}0.323 * * * \\
(0.098)\end{array}$ & $\begin{array}{c}0.050 \\
(0.093)\end{array}$ & $\begin{array}{c}0.281 * * * \\
(0.040)\end{array}$ & $\begin{array}{c}0.565 * * * \\
(0.098)\end{array}$ & $\begin{array}{c}0.081 \\
(0.094)\end{array}$ & $\begin{array}{c}0.422 * * * \\
(0.044)\end{array}$ \\
\hline Constant & $\begin{array}{c}0.091 \\
(0.088)\end{array}$ & $\begin{array}{c}0.091 \\
(0.088)\end{array}$ & $\begin{array}{c}-0.000 \\
-\end{array}$ & $\begin{array}{c}0.091 \\
(0.088)\end{array}$ & $\begin{array}{c}0.091 \\
(0.088)\end{array}$ & $\begin{array}{c}-0.000 \\
-\end{array}$ \\
\hline $\begin{array}{l}\text { Observations } \\
\text { R-squared }\end{array}$ & $\begin{array}{c}240 \\
0.099\end{array}$ & $\begin{array}{c}240 \\
0.045\end{array}$ & $\begin{array}{c}240 \\
0.092\end{array}$ & $\begin{array}{c}240 \\
0.109\end{array}$ & $\begin{array}{c}240 \\
0.035\end{array}$ & $\begin{array}{c}240 \\
0.088\end{array}$ \\
\hline $\begin{array}{l}\text { Notes: Robust st } \\
\text { Five major ranke }\end{array}$ & ICNU & heses. *** & $\begin{array}{l}\text { ans significa } \\
\text { Forbes, The }\end{array}$ & $\%$ level, * & $\begin{array}{l}* \text { at } 5 \% \text {, and } \\
\text { s, and The Ecc }\end{array}$ & $\begin{array}{l}* \text { at } 10 \% \text {. } \\
\text { onomist. }\end{array}$ \\
\hline
\end{tabular}




\begin{tabular}{|c|c|c|c|c|c|}
\hline \multicolumn{6}{|c|}{$\begin{array}{c}\text { Table 4: Test of Branded Schools' Disclosure } \\
\text { Linear Probability Model } \\
\text { Omitted Variable }=\text { Top } 10 \text { Business School } \\
\text { Dependent Variable }=1 \text { if Ranking is Displayed, O Otherwise }\end{array}$} \\
\hline Variable & $\underline{(1)}$ & $\underline{(2)}$ & $\underline{(3)}$ & $\underline{(4)}$ & $\underline{(5)}$ \\
\hline Ranked $11-25$ & $\begin{array}{c}0.105 \\
(0.133)\end{array}$ & $\begin{array}{c}0.043 \\
(0.139)\end{array}$ & $\begin{array}{c}0.047 \\
(0.138)\end{array}$ & $\begin{array}{c}0.150 \\
(0.142)\end{array}$ & $\begin{array}{c}0.032 \\
(0.138)\end{array}$ \\
\hline Ranked 26 - 50 & $\begin{array}{c}0.649 * * * \\
(0.124)\end{array}$ & $\begin{array}{c}0.588 * * * \\
(0.130)\end{array}$ & $\begin{array}{c}0.590 * * * \\
(0.129)\end{array}$ & $\begin{array}{c}0.738 * * * \\
(0.139)\end{array}$ & $\begin{array}{l}0.594 * * * \\
(0.141)\end{array}$ \\
\hline Ranked 51 - 75 & $\begin{array}{c}0.547 * * * \\
(0.125)\end{array}$ & $\begin{array}{c}0.457 * * * \\
(0.138)\end{array}$ & $\begin{array}{c}0.459 * * * \\
(0.137)\end{array}$ & $\begin{array}{c}0.789 * * * \\
(0.157)\end{array}$ & $\begin{array}{c}0.609 * * * \\
(0.166)\end{array}$ \\
\hline Ranked $76-116$ & $\begin{array}{c}0.334 * * * \\
(0.125)\end{array}$ & $\begin{array}{c}0.270 * * \\
(0.132)\end{array}$ & $\begin{array}{c}0.265 * * \\
(0.132)\end{array}$ & $\begin{array}{c}0.546 * * * \\
(0.171)\end{array}$ & $\begin{array}{l}0.329 * \\
(0.177)\end{array}$ \\
\hline Unranked & $\begin{array}{c}0.309 * * * \\
(0.097)\end{array}$ & $\begin{array}{l}0.204^{*} \\
(0.114)\end{array}$ & $\begin{array}{l}0.209^{*} \\
(0.112)\end{array}$ & $\begin{array}{c}0.453 * * \\
(0.187)\end{array}$ & $\begin{array}{c}0.292 \\
(0.182)\end{array}$ \\
\hline $\begin{array}{l}\log (\# \text { times university in NY Times article } \\
\text { search/10,000) }\end{array}$ & $\begin{array}{l}-0.025 \\
(0.022)\end{array}$ & $\begin{array}{l}-- \\
--\end{array}$ & $\begin{array}{l}-0.011 \\
(0.023)\end{array}$ & $\begin{array}{l}-- \\
--\end{array}$ & $\begin{array}{c}-0.064 * * \\
(0.026)\end{array}$ \\
\hline $\begin{array}{l}\log (\# \text { times business school in NY Times } \\
\text { article search/10,000) }\end{array}$ & -- & $\begin{array}{c}-0.041 * * \\
(0.020)\end{array}$ & $\begin{array}{c}-0.038 * \\
(0.022)\end{array}$ & -- & $\begin{array}{c}-0.065^{* *} \\
(0.026)\end{array}$ \\
\hline USNWR Undergraduate Ranking & $\begin{array}{l}-- \\
--\end{array}$ & $\begin{array}{l}-- \\
--\end{array}$ & -- & $\begin{array}{l}-0.002 \\
(0.001)\end{array}$ & $\begin{array}{l}-0.002 \\
(0.001)\end{array}$ \\
\hline Constant & $\begin{array}{c}0.058 \\
(0.086)\end{array}$ & $\begin{array}{l}0.203^{*} \\
(0.105)\end{array}$ & $\begin{array}{c}0.179 \\
(0.112)\end{array}$ & $\begin{array}{c}0.109 \\
(0.090)\end{array}$ & $\begin{array}{l}0.199^{*} \\
(0.116)\end{array}$ \\
\hline $\begin{array}{l}\text { Observations } \\
\text { R-squared }\end{array}$ & $\begin{array}{c}240 \\
0.104\end{array}$ & $\begin{array}{c}240 \\
0.115\end{array}$ & $\begin{array}{c}240 \\
0.116\end{array}$ & $\begin{array}{c}146 \\
0.218\end{array}$ & $\begin{array}{c}146 \\
0.285\end{array}$ \\
\hline
\end{tabular}




\begin{tabular}{|c|c|c|}
\hline \multicolumn{3}{|c|}{$\begin{array}{c}\text { Table 5: Test of Information Shrouding } \\
\text { Linear Probability Model } \\
\text { Omitted Variable }=\text { Top } 10 \text { Business School } \\
\text { Dependent Variable }=1 \text { if Shrouding, O Otherwise }\end{array}$} \\
\hline \multicolumn{3}{|c|}{ Type of Shrouding: } \\
\hline Variable & $\frac{\text { Mentions Top Ranked }}{\frac{\text { With No Supporting }}{\text { Information }}}$ & $\frac{\text { Any Shrouding of }}{\text { Information }}$ \\
\hline Ranked 11 - 25 & $\begin{array}{l}0.200^{*} \\
(0.105)\end{array}$ & $\begin{array}{c}0.176 \\
(0.145)\end{array}$ \\
\hline Ranked 26 - 50 & $\begin{array}{c}0.333 * * * \\
(0.097)\end{array}$ & $\begin{array}{c}0.576 * * * \\
(0.131)\end{array}$ \\
\hline Ranked 51 - 75 & $\begin{array}{l}0.103 * \\
(0.057)\end{array}$ & $\begin{array}{c}0.495 * * * \\
(0.128)\end{array}$ \\
\hline Ranked $76-116$ & $\begin{array}{r}0.152^{* * *} \\
(0.063)\end{array}$ & $\begin{array}{c}0.424 * * * \\
(0.124)\end{array}$ \\
\hline Unranked & $\begin{array}{c}0.070 * * * \\
(0.023)\end{array}$ & $\begin{array}{c}0.362 * * * \\
(0.098)\end{array}$ \\
\hline Constant & $\begin{array}{c}-0.000 \\
-\end{array}$ & $\begin{array}{c}0.091 \\
(0.088)\end{array}$ \\
\hline $\begin{array}{l}\text { Observations } \\
\text { R-squared }\end{array}$ & $\begin{array}{c}240 \\
0.069\end{array}$ & $\begin{array}{c}240 \\
0.061\end{array}$ \\
\hline $\begin{array}{l}\text { Notes: Robust star } \\
\text { significant at } 1 \% \text { le } \\
\text { major rankers inch } \\
\text { The Financial Time } \\
\text { USNWR. Only in }\end{array}$ & $\begin{array}{l}\text { dard errors in paranthe } \\
\text { el, ** at } 5 \% \text {, and * at } \\
\text { de USNWR, Business } \\
\text {, and The Economist. } \\
\text { ludes U.S. programs. }\end{array}$ & $\begin{array}{l}\text { eses. } * * * \text { means } \\
10 \% \text {. Five } \\
\text { Week, Forbes, } \\
\text { Ranks from }\end{array}$ \\
\hline
\end{tabular}




\begin{tabular}{|c|c|c|}
\hline \multicolumn{3}{|c|}{$\begin{array}{c}\text { Table 6: Test of Selective Disclosure } \\
\text { Linear Probability Model } \\
\text { Omitted Variable }=\text { Top } 10 \text { Business School } \\
\text { Dependent Variable }=1 \text { if Selectively Disclose, O Otherwise }\end{array}$} \\
\hline & \multicolumn{2}{|c|}{ Type of Selective Disclosure: } \\
\hline Variable & $\frac{\frac{\text { School's Website }}{\text { Mentions Princeton }}}{\text { Review Overall Rank }}$ & $\frac{\text { School's Website Mentions }}{\underline{A A C S B \text { Certification }}}$ \\
\hline Ranked 11 - 25 & $\begin{array}{c}0.000 \\
(0.000)\end{array}$ & $\begin{array}{c}0.067 \\
(0.065)\end{array}$ \\
\hline Ranked 26 - 50 & $\begin{array}{c}0.000 \\
(0.000)\end{array}$ & $\begin{array}{c}0.208^{* *} \\
(0.084)\end{array}$ \\
\hline Ranked 51 - 75 & $\begin{array}{c}0.069 \\
(0.048)\end{array}$ & $\begin{array}{c}0.345 * * * \\
(0.089)\end{array}$ \\
\hline Ranked 76 - 116 & $\begin{array}{l}0.091 * \\
(0.051)\end{array}$ & $\begin{array}{c}0.636^{* * * *} \\
(0.085)\end{array}$ \\
\hline Unranked & $\begin{array}{c}0.305^{* * *} * \\
(0.041)\end{array}$ & $\begin{array}{c}0.781 * * * \\
(0.037)\end{array}$ \\
\hline Constant & $\begin{array}{l}-0.000 \\
(0.000)\end{array}$ & $\begin{array}{l}-0.000 \\
(0.000)\end{array}$ \\
\hline Observations & 240 & 240 \\
\hline R-squared & 0.118 & 0.303 \\
\hline \multicolumn{3}{|c|}{$\begin{array}{l}\text { Notes: Robust standard errors in parantheses. } * * * \text { means significant a } \\
1 \% \text { level, } * * \text { at } 5 \% \text {, and } * \text { at } 10 \% \text {. Princeton Review does not } \\
\text { explicitly rank school but rather pools into approximately top } 300 \\
\text { schools. AACSB accredits approximatel } 5 \% \text { of worldwide business } \\
\text { schools. Ranks from USNWR. Only includes U.S. programs. }\end{array}$} \\
\hline
\end{tabular}




\section{$\underline{\text { Figures }}$}
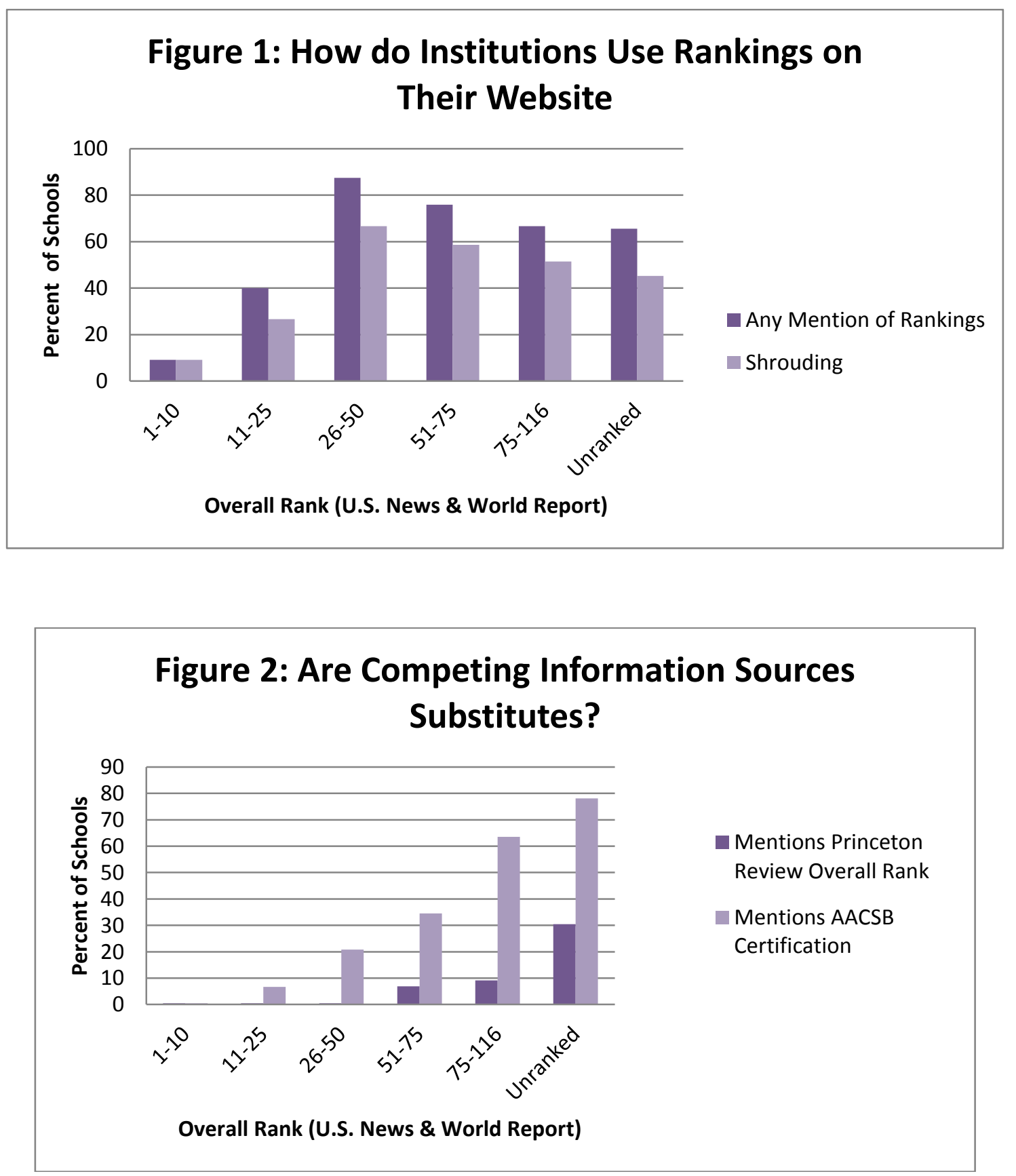


\section{$\underline{\text { Appendix }}$}

\begin{tabular}{|c|c|c|}
\hline \multicolumn{3}{|c|}{ Appendix 1: Sources and Type of Rankings } \\
\hline$\underline{\text { Source }}$ & Type & $\frac{\text { Number of }}{\text { Programs Ranked }^{*}}$ \\
\hline 1 USNWR & Overall Business School & 112 \\
\hline 2 USNWR & Accounting & 32 \\
\hline 3 USNWR & Entrepreneurship & 27 \\
\hline 4 USNWR & Executive MBA & 24 \\
\hline 5 USNWR & Finance & 28 \\
\hline 6 USNWR & Information Systems & 21 \\
\hline 7 USNWR & International & 21 \\
\hline 8 USNWR & Management & 21 \\
\hline 9 USNWR & Marketing & 24 \\
\hline 10 USNWR & Non-profit & 10 \\
\hline 11 USNWR & Part-time & 192 \\
\hline 12 USNWR & Productions/Operations & 24 \\
\hline 13 USNWR & Supply Chain/Logistics & 24 \\
\hline 14 Business Week & Overall Business School & 57 \\
\hline 15 Business Week & Executive MBA & 31 \\
\hline 16 Business Week & Part-time & 74 \\
\hline 17 Business Week & Part-time Mid-Atlantic Region & 10 \\
\hline 18 Business Week & Part-time Midwest Region & 18 \\
\hline 19 Business Week & Part-time Northeast Region & 9 \\
\hline 20 Business Week & Part-time South Region & 14 \\
\hline 21 Business Week & Part-time Southwest Region & 8 \\
\hline 22 Business Week & Part-time West Region & 15 \\
\hline 23 Business Week & Executive Education - Open Enrollment & 12 \\
\hline 24 Business Week & Executive Education - Custom Program & 10 \\
\hline 25 Forbes & Overall Business School & 73 \\
\hline 26 The Economist & Overall Business School & 47 \\
\hline 27 Financial Times & Overall Business School & 53 \\
\hline 28 Princeton Review & Entrepreneurship & 24 \\
\hline 29 Princeton Review & Administered & 10 \\
\hline 30 Princeton Review & Campus Environment & 10 \\
\hline 31 Princeton Review & Campus Facilities & 10 \\
\hline 32 Princeton Review & Career & 9 \\
\hline 33 Princeton Review & Classroom & 9 \\
\hline 34 Princeton Review & Professors & 10 \\
\hline 35 Princeton Review & Minorities & 9 \\
\hline 36 Princeton Review & Women & 10 \\
\hline 37 Princeton Review & Family Friendly & 10 \\
\hline 38 Princeton Review & Toughest Entry & 10 \\
\hline
\end{tabular}




\begin{tabular}{|l|}
\hline \multicolumn{1}{|c|}{ Appendix 2: Types of Shrouding on Website } \\
\hline 1 Says top ranked but provides no additional information. \\
2 Says top ranked but provides partial information. \\
3 Says top ranked but puts links to information on another webpage. \\
4 Presents ranking from past years. \\
5 Pools into tiers (e.g. ranked \#20 but says among the top 20). \\
6 Converts into percent (e.g. ranked \#20 but says ranked in top 5\%). \\
7 Prominently says top ranked and fine print provides details. \\
8 Displays the logo of ranker with no additional information. \\
9 Says top ranked business school but does not say it is a specialty \\
ranking (e.g. executive MBA).
\end{tabular}




\begin{tabular}{|c|c|c|c|}
\hline \multicolumn{4}{|c|}{$\begin{array}{c}\text { Appendix 3: Which Business Schools Mention Ranking on Website } \\
\text { Using Best Overall Rank } \\
\text { Linear Probability Model } \\
\text { Omitted Variable }=\text { Top 10 Business School }\end{array}$} \\
\hline \multirow[b]{2}{*}{ Variable } & \multicolumn{3}{|c|}{ School's Website Mentions (five major rankers): } \\
\hline & Any Rank & Overall Rank & Specialty Rank \\
\hline Ranked 11 - 25 & $\begin{array}{l}0.256^{*} \\
(0.146)\end{array}$ & $\begin{array}{c}0.156 \\
(0.119)\end{array}$ & $\begin{array}{c}0.322^{* * *} \\
(0.133)\end{array}$ \\
\hline Ranked 26 - 50 & $\begin{array}{c}0.581 * * * \\
(0.124)\end{array}$ & $\begin{array}{c}0.219 * * \\
(0.108)\end{array}$ & $\begin{array}{c}0.469 * * * \\
(0.116)\end{array}$ \\
\hline Ranked 51 - 75 & $\begin{array}{c}0.480 * * * \\
(0.126)\end{array}$ & $\begin{array}{c}0.095 \\
(0.093)\end{array}$ & $\begin{array}{c}0.385 * * * \\
(0.112)\end{array}$ \\
\hline Ranked 76 - 116 & $\begin{array}{c}0.283^{* *} \\
(0.135)\end{array}$ & $\begin{array}{c}0.058 \\
(0.094)\end{array}$ & $\begin{array}{c}0.142 \\
(0.106)\end{array}$ \\
\hline Unranked & $\begin{array}{c}0.278^{* * * *} \\
(0.100)\end{array}$ & $\begin{array}{c}0.062 \\
(0.072)\end{array}$ & $\begin{array}{c}0.224 * * * \\
(0.077)\end{array}$ \\
\hline Constant & $\begin{array}{c}0.133 \\
(0.089)\end{array}$ & $\begin{array}{c}0.067 \\
(0.065)\end{array}$ & $\begin{array}{c}0.067 \\
(0.065)\end{array}$ \\
\hline $\begin{array}{l}\text { Observations } \\
\text { R-squared }\end{array}$ & $\begin{array}{c}240 \\
0.077\end{array}$ & $\begin{array}{c}240 \\
0.025\end{array}$ & $\begin{array}{c}240 \\
0.062\end{array}$ \\
\hline \multicolumn{4}{|c|}{$\begin{array}{l}\text { Notes: Robust standard errors in parantheses. } * * * \text { means significant at } 1 \% \text { level, } * * \text { at } \\
5 \% \text {, and } * \text { at } 10 \% \text {. Five major rankers include USNWR, Business Week, Forbes, } \\
\text { The Financial Times, and The Economist. Other rankers include Princeton Review's } \\
\text { specialty ranks (not overall pooled rank) and other news sources. Only includes U.S. } \\
\text { programs. }\end{array}$} \\
\hline
\end{tabular}




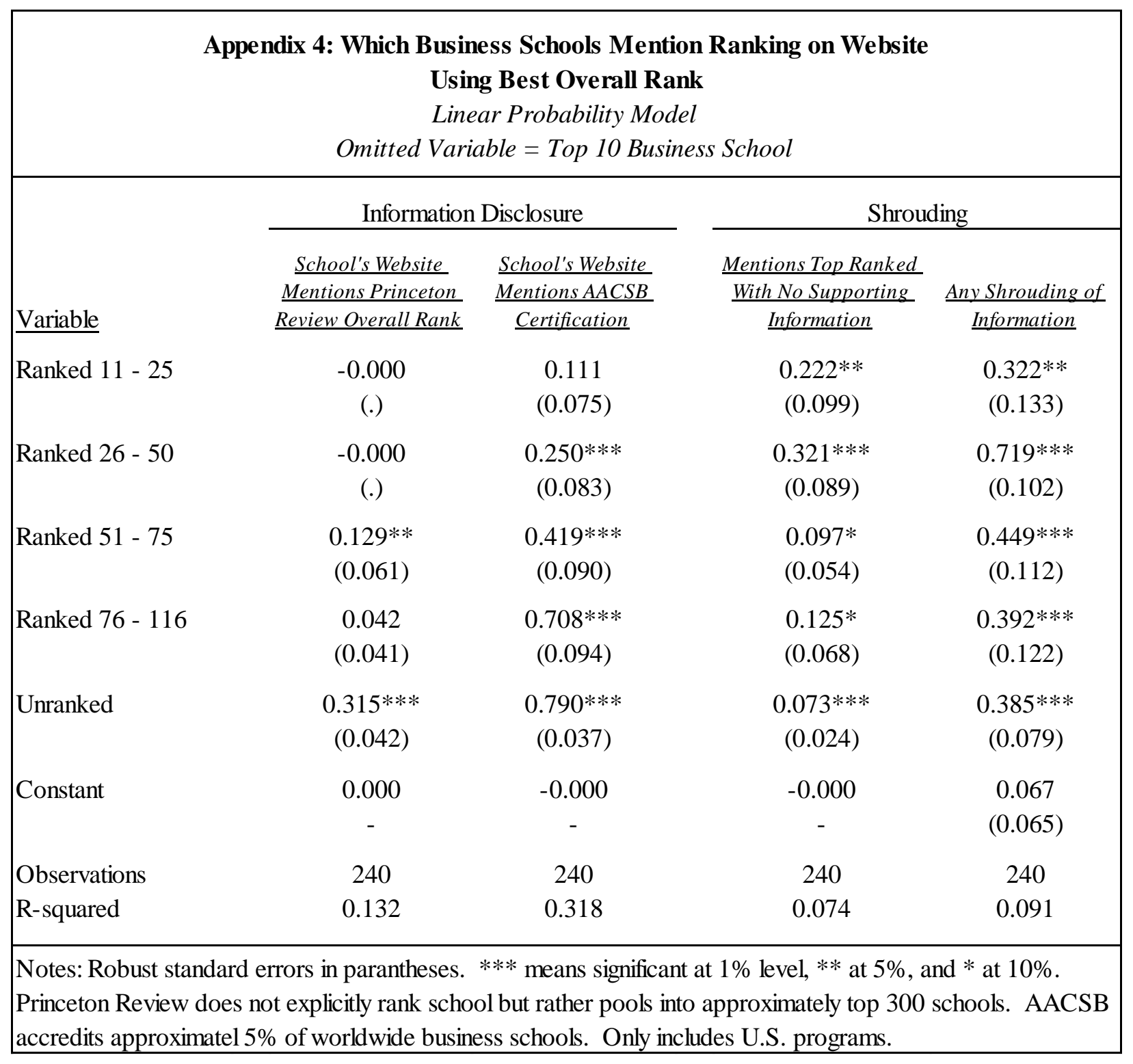

